\title{
IGF-binding protein 2 - oncogene or tumor suppressor?
}

\section{Adam Pickard * and Dennis J. McCance}

Centre for Cancer Research and Cell Biology, Queen's University, Belfast, UK

\section{Edited by:}

Antonino Belfiore, University Magna

Graecia of Catanzaro, Italy

Reviewed by:

Andrea Morrione, Thomas Jefferson University, USA

Elahu Gosney Sustarsic, Ludwig

Maximilian University, Germany

*Correspondence:

Adam Pickard, Centre for Cancer

Research and Cell Biology, Queen's

University Belfast, 97 Lisburn Road,

Belfast BT7 9BL, UK

e-mail: a.pickard@qub.ac.uk
The role of insulin-like growth factor binding protein 2 (IGFBP2) in cancer is unclear. In general, IGFBP2 is considered to be oncogenic and its expression is often observed to be elevated in cancer. However, there are a number of conflicting reports in vitro and in vivo where IGFBP2 acts in a tumor suppressor manner. In this mini-review, we discuss the factors influencing the variation in IGFBP2 expression in cancer and our interpretation of these findings.

Keywords: IGF1, IGFI, IGF2, IGF-II, IGFBPs, IGFBP2, oncogenes, tumour suppressor

\section{INTRODUCTION}

Insulin-like growth factor binding protein 2 is a member of the family of six IGF-binding proteins, IGFBP1-6, these proteins bind with high-affinity to IGF1 and IGF2 (1); in addition, there is also a low affinity for insulin (2). Other IGF-binding proteins such as the CCN family retain the name as IGFBPs, although these have $~ 100$-fold lower affinity for IGF1 and IGF2 $(1,3,4)$. IGFBP2 has the ability to bind insulin, IGF1 and IGF2 with an increased affinity for the latter $(2,5)$. IGFBP2 and the other family members have been proposed to suppress tumor development through binding IGFs preventing binding to their receptor and thereby preventing IGF driven tumorigenesis (6). However, despite this suppressive function, there are also studies that demonstrate oncogenic functions including promoting proliferation, driving invasion, and suppressing apoptosis (7). These effects appear to be independent of its ability to bind the IGFs and instead promote invasion and proliferation through interaction with integrins $(8,9)$.

Insulin-like growth factor binding protein 2 has been proposed as a potential biomarker in various cancer types, including gliomas (10-18), prostate (19-27), ovarian (28-33) colorectal (34-40) and acute myeloid leukemia (13, 41, 42), acute lymphoblastic leukemia $(43,44)$ pancreatic (45-48), lung (49-52), cervical cancer $(53)$, breast $(54,55)$ including triple negative breast cancer (56), liver (57-60), head and neck (61), rhabdomyosarcoma (62), non-seminomatous germ cell cancer (63), gastric (64), synovial sarcoma (65), adrenocortical (66), and Wilm's tumors (67). These studies have identified changes in tissue levels or circulating plasma levels of IGFBP2 protein, although it is not yet clear whether tumor or circulating levels are better as cancer biomarkers as each approach provides conflicting data. Despite this extensive investigation, IGFBP2 has not yet been implemented as a cancer biomarker due to contradictory findings as to whether IGFBP2 is up- or down-regulated in different cancers. There are multiple factors, which can influence IGFBP2 expression and which can alter our interpretation of these findings; in the following sections, we propose that future experiments should aim to account for these factors in order to improve our understanding of IGFBP2's role in cancer.

\section{METABOLIC/DIETARY MODULATION OF IGFBP2}

Insulin-like growth factor binding protein 2 is being evaluated as a potential cancer biomarker as it is a secreted protein that is readily detected in a patients' plasma; higher levels have repeatedly been associated with disease severity in prostate cancer and gliomas. However, there are also inconsistent finding, which makes evaluation of IGFBP2's oncogenic/tumor suppressive role difficult and also questions the suitability of IGFBP2 as a biomarker (68). Therefore, it is important to consider whether there are confounding factors, which obscure our interpretation. Plasma levels of IGFBP2 are known to inversely correlate with obesity/body mass index (BMI) (69-76), and insulin resistance. In addition, diet (77), fasting (78), age, and physical activity (79) also influence IGFBP2 plasma levels. If not included within the study design, these factors are likely to hinder our evaluation of IGFBP2 as a biomarker. The importance of combining these parameters along with measurements of IGFBP2 levels is demonstrated by ProbstHensch et al. (80). By combining BMI and the levels of IGFBP2 and IGFBP3 in assessment of breast cancer patient survival, the authors demonstrated that without correction for BMI neither IGFBP2 nor IGFBP3 were predictive of overall survival, whereas inclusion of BMI identified that higher IGFBP2 levels to be a beneficial prognosticator. This is an interesting finding as it is generally considered that IGFBP2 is oncogenic in breast cancer $(55,81)$; however, these other studies did not correct for factors such as BMI. Similarly, the influence of obesity has been examined with respect to the levels of IGFBP2, with lower levels observed in obese patients, which has been proposed to be a result of hyperinsulinemia, with insulin suppressing IGFBP2 expression (82). This has been linked with the subsequent increase in proliferation mediated by free-IGFs and thereby increasing the risk of cancer in obese individuals (82). In some respects, this interpretation is complemented by data in IGFBP2 transgenic mice, which have 
reduced body mass (83) and incidence of colorectal adenomas in experimental models (84).

\section{REGULATION OF IGFBP2 EXPRESSION AT A CELLULAR LEVEL}

Given the difficulties in accurately associating plasma levels of IGFBP2 with cancer patient prognosis or disease progression, as well as reports demonstrating a lack of concordance between tumor immunohistochemistry (IHC) and serum levels of IGFBP2 $(12,52,85-87)$, it may be more meaningful to assess the expression of IGFBP2 within the tumor itself. IGFBP2 is mainly expressed by the liver, adipose, and reproductive tissues and tissues of the central nervous system (4). However, IGFBP2 is also expressed in a wide range of other tissue types, including both epithelial and mesenchymal cells [see Ref. (88), proteinatlas.org (89), and encode (90)], therefore the local levels of IGFBP2 are likely to play an important part in how the tissue responds to circulating IGFs. Approaches to detect changes in protein or RNA levels of IGFBP2 within tumors have been used to hint at whether IGFBP2 might act in a tumor suppressive or oncogenic manner, however, within a given tumor type the expression of IGFBP2 can vary greatly, so below we examine the mechanisms, which regulate IGFBP2 expression in tumors.

\section{PROMOTER METHYLATION}

Promoters, including the IGFBP2, can become hyper- or hypomethylated relative to the normal state during tumorigenesis. The IGFBP2 promoter has been shown to be hypermethylated, in a subset of tumors, including $8 \%$ of small cell lung carcinomas (86), $>20 \%$ of renal cell carcinomas (91), $\sim 30 \%$ squamous cell lung cancers (86), $40 \%$ of colorectal cancers (92), $>70 \%$ lung adenocarcinomas (86), and 75\% hepatomas (93). The hypermethylation results in reduced IGFBP2 expression, as demonstrated by Yazawa et al. with good correlation between IGFBP2 promoter methylation and IGFBP2 protein expression detected by IHC (86). The low expression of IGFBP2 observed in some glioblastoma cell lines, is associated with methylation of the IGFBP2 promoter and can be restored with 5-azacytadine treatment suggesting regulation by DNA methyltransferase 1 (DNMT1) (94). Also, DNMT3L knockdown in embryonic stem cells results in elevated IGFBP2 expression (95), suggesting promoter methylation is an important regulator of IGFBP2 expression. The observation that IGFBP2 is hypermethylated in lung and liver cancers is somewhat surprising as elevated plasma levels have been described for these diseases $(57,87)$; however, the higher plasma levels of IGFBP2 may represent a systemic response to cancer, or the confounding factors described above. Further assessment of the inactivation of the IGFBP2 locus will be greatly aided by The Cancer Genome Atlas project (http://cancergenome.nih.gov/).

\section{NORMAL VERSUS ABERRANT REGULATION}

Insulin-like growth factor binding protein 2 expression is greatly influenced by hormonal factors and both positive and negative regulators of IGFBP2 expression have been described, as reviewed in Ref. (88). Interestingly, the same hormone can have differing effects depending upon the tissue. As an example, estradiol (E2) acts on the hippocampus to increase IGFBP2 expression (96) whereas in the cortex IGFBP2 expression is reduced (97). Estradiol also reflects an interesting example of how we interpret the role of IGFBP2 in cancer, as previously described, IGFBP2 is generally considered to be oncogenic in breast cancer; however, IGFBP2 expression, in vivo, is induced by estradiol in normal breast tissue (98), whereas in the rat mammary adenocarcinoma, R3230AC, IGFBP2 expression is reduced following E2 treatment (99). In the breast cancer cell line, MCF7 IGFBP2 expression is also elevated by E2 (100), suggesting that this cell line is responding in the same way as normal tissue. Estrogen receptor (ER) status directly correlates with IGFBP2 expression in breast cancer, with ER-positive cancers having higher levels of IGFBP2 than ER-negative cancers $(80,101,102)$, and therefore the high levels of IGFBP2 may simply reflect a functional ER pathway. In order to better understand whether regulation of IGFBP2 expression is de-regulated in cancer, it will be important to further establish how it is regulated in the physiological setting.

\section{REGULATION BY PROTEASES}

In addition to the aforementioned disconnect between plasma levels and tumor levels of IGFBP2, there are also reports demonstrating that IGFBP2 mRNA and protein levels do not always correlate (103). Protease cleavage of IGFBP2 could be partially responsible for the lack of association, and also help to explain the differential findings of IGFBP2's role in cancer. There are a number of proteases, which cleave the mature IGFBP2 peptide, these include calpain (104), pappalysin A (105), kallikrein-2 (106), and MMP7 (107). Plasmin and MMP1 also cleave IGFBP2; however, the cleavage sites have not been defined (108). In addition, IGFBP2 is also cleaved at additional sites; however, the responsible proteases have not been identified (109). IGFBP2 cleavage reduces its affinity for IGFI and IGF2 (110-112), allowing IGFs to mediate their functions through the IGF1R. Thus, it is important to reflect on the nature of IGFBP2 in carcinogenesis as calpain (113), MMP1 (114), MMP7 (114), and kallikrein-related peptidases (115) have also been described to be elevated or activated in various cancer types and may lead to inactivation of the protein. Many reagents used to detect the IGFBP2 protein are not able to distinguish whether IGFBP2 is in its full-length form. Fragments of IGFBP2 can be detected by the antibodies often used for immunohistochemical detection of IGFBP2 (110). To our knowledge, only one report has assessed IGFBP2 expression with multiple antibodies, targeting the $\mathrm{C}$ and $\mathrm{N}$ termini of IGFBP2. This work demonstrated a correlation between a cleaved $\mathrm{N}$-terminal fragment of IGFBP2 and the protease ADAMTS1 in glioblastoma (116) suggesting IGFBP2 is not in a full-length form and therefore may be unable to bind IGFs.

Insulin-like growth factor binding protein 2 cleavage may result in enhanced proliferation mediated by IGFs but it has also been proposed that the cleaved fragments of IGFBP2 have additional roles. C-terminal fragments of IGFBP2 are able to promote proliferation of rat chondrocytes (117), and a recent report, which demonstrates that nuclear IGFBP2 can drive VEGF expression demonstrated that a nuclear localization sequence (NLS) is present in the linker region of IGFBP2 (118); interestingly, this region is the site of many cleavage events and may lead to exposure of the NLS.

The importance of establishing whether IGFBP2 is cleaved in cancer tissue has recently been demonstrated by Soh et al. (108), 
where a protease-resistant IGFBP2 was more effective at inhibiting IGF1-induced proliferation of the MCF7 cell line than wild-type IGFBP2. Interestingly, protease resistant IGFBP2 was also able to suppress tumor growth in vivo. Furthermore, the MCF7 cell line is known to secrete low levels of full-length IGFBP2 compared to other cancer cell lines even though the mRNA and intracellular protein levels of IGFBP2 are comparable (119), suggesting high levels of proteolytic degradation.

Reflecting on the cleaved status of IGFBP2 in cancer may also help to explain some of the contradictory evidence regarding its tumor suppressive/oncogenic role in carcinogenesis. For example, the elevated expression of the IGFBP2 protein observed in various cancers may represent a response to suppress tumor growth, mediated by IGFs; however, pro-tumorigenic proteases may ultimately inactivate this response. Enhanced proteolysis of IGFBP2 has been described in proliferating cells, and can be inhibited by targeting proteases (120). Therefore, the observation that a protease-resistant IGFBP2 can suppress tumor growth (108) creates the exciting opportunity to target proteases and potentially restore the suppressive actions of IGFBP2.

\section{INTRA-TUMOR VARIABILITY}

In addition to the variation of IGFBP2 expression between different tumors, there is also further variation of IGFBP2 expression levels, within an individual tumor. While high grade glioblastoma, which are frequently observed to have elevated IGFBP2 level, also have regions of reduced IGFBP2 expression, which have been shown to be at the invasive front of the tumor (121). Therefore, this data would suggest that IGFBP2 loss correlates with enhanced invasive potential, as observed in other models (59). Interestingly, this is also supported by an in vivo model of malignant brain tumor growth and invasion, where rapidly growing non-invasive tumors have high levels of IGFBP2 compared to invasive tumors, which had low/undetectable IGFBP2 levels (122). Furthermore, the oxygenation of a tumor varies depending on blood supply to different regions of the tumor, hypoxia has been shown to regulate IGFBP2 expression $(88,123-126)$ and should also be considered when scoring IGFBP2 expression in tumor samples.

\section{REGULATION OF IGFBP2 EXPRESSION BY TUMOR SUPPRESSORS AND ONCOGENES}

There are a number of additional factors, which are known to influence IGFBP2 expression, and therefore how we evaluate its role in cancer. There are now a number of reports, which demonstrate a connection between PTEN levels and those of IGFBP2 (127-130). PTEN mutation in glioma is associated with high levels of IGFBP2 (130) suggesting that IGFBP2 could be a marker of PTEN mutation. Similarly, mutation of KRAS also induces IGFBP2 expression (131). IGFBP2 expression has also been shown to correlate with TP53 mutational status. While it has been demonstrated that wildtype p53 is required for IGFBP2 induction following irradiation (132), the regulation of IGFBP2 by p53 mutations is, at present, unclear. In breast cancer, p53 mutation is associated with reduced secretion of IGFBP2 (133), whereas in glioblastoma, mutant p53 is associated with high levels of IGFBP2 (94). In addition, Ras mutation, loss of p53 and radiation-induced DNA damage drives a senescence-associated secretory phenotype (SASP), of which, elevated IGFBP2 secretion is a component (134). This is also supported by evidence that mRNA expression is also elevated in senescence (135-137). Together these findings suggest that the variation in IGFBP2 expression in tumors may reflect the status of tumor suppressors, oncogenes, and/or use of radiation therapy, therefore, the tumor suppressive/oncogenic potential of IGFBP2 should now be evaluated in the context of each mutation in order to demonstrate whether or not IGFBP2 has a functional role.

\section{CORRELATION OF IGFBP2 EXPRESSION WITH CANCER PROGRESSION}

It has been established that enhanced expression of IGFBP2 is associated with the progression of tumorigenesis in prostate (27), breast cancer (138), and glioma (7); however, when the expression of IGFBP2 is examined further it appears that there are certain cancer types or subpopulations of cancers, which develop with little or no expression of IGFBP2. This latter finding goes against the hypothesis of IGFBP2 being a driver of tumorigenesis, and suggests that loss of IGFBP2 may also be an important event in tumors. A detailed examination of ovarian cancers observed that IGFBP2 expression did not correlate with stage of disease (139), with similar proportions of tumors having low or high expression of IGFBP2 at all stages. Interestingly, in the same study, the authors demonstrate that the expression of IGFBP2 is related to the type of ovarian cancer, for example, $80 \%$ of serous carcinoma had elevated IGFBP 2 whereas $80 \%$ of clear cell carcinoma had low IGFBP2 levels. Similarly, in lung cancer, IGFBP2 is found to be overexpressed in the majority of small cell lung carcinomas but reduced in the majority of lung adenocarcinomas (86). Thus, it is important to consider whether these results demonstrate a correlation of IGFBP2 driving tumorigenesis or are, in fact, reflective of tumor stage/subtype. These findings suggest that cancers can develop both in the presence and absence of IGFBP2 and as cancer sub-types become further defined it will be important to evaluate how IGFBP2 expression is regulated among these different groups. Evaluation of IGFBP2's role in each group will then provide a better understanding of it oncogenic and tumor suppressive potential.

\section{THERAPEUTIC RESPONSE AND IGFBP2}

Evaluation of IGFBP2 as a biomarker in the treatment of cancer has also generated a dichotomy in how IGFBP2 is perceived. In some cases, IGFBP2 is found to be a marker of response to therapy but then others have demonstrated that high levels confer resistance. In the case of IGF1R targeted therapies, McCaffery et al. (47) demonstrated that there was better response to IGF1R targeted therapy in patients with low IGFBP2 levels, than patients with high IGFBP2 and similar results were found in a mouse model where inhibition with the IGF1R inhibitor BMS-536924, had no effect in reducing growth of cells expressing high levels of IGFBP2 (140). However, down-regulation of IGFBP2 in rhabdomyosarcoma is associated with resistance to IGF1R therapy (141). In response to other therapeutic strategies, tumor samples from patients receiving chemotherapy/radiotherapy have been shown to have elevated IGFBP2 levels and suggest that IGFBP2 is a potential marker of response to these treatments (134) and may be due to a pro-apoptotic function of IGFBP2 (142). However, high levels of 
IGFBP2 are also linked with resistance to other therapeutics (143146) and high levels of IGFBP2 following radio/chemotherapy also correlate with poor survival in elderly patients with glioblastoma (147). Therefore, further evaluation of IGFBP2 in response to therapy is an area, which requires further investigation.

\section{DIFFERENTIAL FUNCTIONS OF IGFBP2}

The binding to IGF1 and IGF2 is common to in vitro models, which demonstrate either oncogenic or tumor suppressive functions of IGFBP2 (148). In addition to repressing IGF signaling, IGFindependent functions have also been described. Overexpression or addition of recombinant IGFBP2 activates integrin complexes with integrins $\alpha 5$ and $\beta 1$ mediating the effects of IGFBP2 (142, 149-151). Through these pathways IGFBP2 reduces adhesion and promotes proliferation and invasion, some of these activities are also observed in cell lines that lack the IGF1-receptor (142) and therefore helps to explain the dichotomy of IGFBP2 functions in vitro and may also explain the association of high levels of IGFBP2 with high grade tumors, despite its inhibitory effect on IGF signaling. It is important to note that these observations have been made following addition of $100-2000 \mathrm{ng} / \mathrm{mL}$ recombinant IGFBP2, while these levels are within the physiological range of human plasma these are greater than the levels secreted by cell lines in culture (151).

\section{CONCLUSION}

While there is conflicting evidence as to whether IGFBP2 is tumor suppressive or oncogenic, this mini-review highlights a number of factors, which influence our interpretation of these findings. Through detailing factors, which influence IGFBP2 expression alongside measurements in patient samples our current understanding of its role in cancer could be improved. So far, it is clear that IGFBP2 has profound effects on cancer cell biology both in vitro and in vivo and therefore warrants further evaluation of IGFBP2 either as a biomarker or even as a therapeutic. The tumor suppressive functions of IGFBP2 align with its ability to bind IGFs while its oncogenic properties of IGFBP2 appear to be IGF-independent. In the future assessment of IGFBP2's role in cancer, it will be important to consider (i) should IGFBP2 levels be assessed in plasma or the tumor/tumor microenviroment? and (ii) can we assess the activity status of IGFBP2 alongside expression levels? either through measuring IGFBP2 cleavage or through development of a functional assay. Further avenues will also likely assess whether IGFBP2 is a predictive biomarker for therapeutic response.

\section{REFERENCES}

1. Yu H, Rohan T. Role of the insulin-like growth factor family in cancer development and progression. J Natl Cancer Inst (2000) 92(18):1472-89. doi:10.1093/jnci/92.18.1472

2. Yamanaka Y, Wilson EM, Rosenfeld RG, Oh Y. Inhibition of insulin receptor activation by insulin-like growth factor binding proteins. J Biol Chem (1997) 272(49):30729-34. doi:10.1074/jbc.272.49.30729

3. Holbourn KP, Acharya KR, Perbal B. The CCN family of proteins: structurefunction relationships. Trends Biochem Sci (2008) 33(10):461-73. doi:10.1016/ j.tibs.2008.07.006

4. Shimasaki S, Ling N. Identification and molecular characterization of insulinlike growth factor binding proteins (IGFBP-1, -2, -3, -4, -5 and -6). Prog Growth Factor Res (1991) 3(4):243-66. doi:10.1016/0955-2235(91)90003-M
5. Oh Y, Müller HL, Lee DY, Fielder PJ, Rosenfeld RG. Characterization of the affinities of insulin-like growth factor (IGF)-binding proteins 1-4 for IGF-I, IGF-II, IGF-I/insulin hybrid, and IGF-I analogs. Endocrinology (1993) 132(3):1337-44. doi:10.1210/endo.132.3.7679979

6. Pollak MN, Schernhammer ES, Hankinson SE. Insulin-like growth factors and neoplasia. Nat Rev Cancer (2004) 4(7):505-18. doi:10.1038/nrc1387

7. Fukushima $\mathrm{T}$, Kataoka $\mathrm{H}$. Roles of insulin-like growth factor binding protein-2 (IGFBP-2) in glioblastoma. Anticancer Res (2007) 27(6A):3685-92.

8. Wang GK, Hu L, Fuller GN, Zhang W. An interaction between insulin-like growth factor-binding protein 2 (IGFBP2) and integrin alpha5 is essential for IGFBP2-induced cell mobility. J Biol Chem (2006) 281(20):14085-91. doi:10.1074/jbc.M513686200

9. Oh SH, Lee OH, Schroeder CP, Oh YW, Ke S, Cha HJ, et al. Antimetastatic activity of insulin-like growth factor binding protein-3 in lung cancer is mediated by insulin-like growth factor-independent urokinase-type plasminogen activator inhibition. Mol Cancer Ther (2006) 5(11):2685-95. doi:10.1158/1535-7163.MCT-06-0142

10. Scrideli CA, Carlotti CG, Mata JF, Neder L, Machado HR, Oba-Sinjo SM, et al. Prognostic significance of co-overexpression of the EGFR/IGFBP-2/HIF-2A genes in astrocytomas. J Neurooncol (2007) 83(3):233-9. doi:10.1007/s11060007-9328-0

11. McDonald KL, O'Sullivan MG, Parkinson JF, Shaw JM, Payne CA, Brewer JM, et al. IQGAP1 and IGFBP2: valuable biomarkers for determining prognosis in glioma patients. J Neuropathol Exp Neurol (2007) 66(5):405-17. doi:10.1097/nen.0b013e31804567d7

12. Lin Y, Jiang T, Zhou K, Xu L, Chen B, Li G, et al. Plasma IGFBP-2 levels predict clinical outcomes of patients with high-grade gliomas. Neuro Oncol (2009) 11(5):468-76. doi:10.1215/15228517-2008-114

13. Müller HL, Oh Y, Lehrnbecher T, Blum WF, Rosenfeld RG. Insulin-like growth factor-binding protein-2 concentrations in cerebrospinal fluid and serum of children with malignant solid tumors or acute leukemia. J Clin Endocrinol Metab (1994) 79(2):428-34. doi:10.1210/jcem.79.2.7519190

14. Santosh V, Arivazhagan A, Sreekanthreddy P, Srinivasan H, Thota B, Srividya MR, et al. Grade-specific expression of insulin-like growth factor-binding proteins-2, -3 , and -5 in astrocytomas: IGFBP- 3 emerges as a strong predictor of survival in patients with newly diagnosed glioblastoma. Cancer Epidemiol Biomarkers Prev (2010) 19(6):1399-408. doi:10.1158/1055-9965.EPI-09-1213

15. Zhou YH, Hess KR, Liu L, Linskey ME, Yung WK. Modeling prognosis for patients with malignant astrocytic gliomas: quantifying the expression of multiple genetic markers and clinical variables. Neuro Oncol (2005) 7(4):485-94. doi:10.1215/S1152851704000730

16. Marucci G, Morandi L, Magrini E, Farnedi A, Franceschi E, Miglio R, et al. Gene expression profiling in glioblastoma and immunohistochemical evaluation of IGFBP-2 and CDC20. Virchows Arch (2008) 453(6):599-609. doi: $10.1007 / \mathrm{s} 00428-008-0685-7$

17. Sandoval JA, Hoelz DJ, Woodruff HA, Powell RL, Jay CL, Grosfeld JL, et al. Novel peptides secreted from human neuroblastoma: useful clinical tools? J Pediatr Surg (2006) 41(1):245-51. doi:10.1016/j.jpedsurg.2005.10.048

18. Nordqvist AC, Peyrard M, Pettersson H, Mathiesen T, Collins VP, Dumanski JP, et al. A high ratio of insulin-like growth factor II/insulin-like growth factor binding protein 2 messenger RNA as a marker for anaplasia in meningiomas. Cancer Res (1997) 57(13):2611-4.

19. Kanety H, Madjar Y, Dagan Y, Levi J, Papa MZ, Pariente C, et al. Serum insulinlike growth factor-binding protein-2 (IGFBP-2) is increased and IGFBP-3 is decreased in patients with prostate cancer: correlation with serum prostatespecific antigen. J Clin Endocrinol Metab (1993) 77(1):229-33. doi:10.1210/ jcem.77.1.7686915

20. Tennant MK, Thrasher JB, Twomey PA, Birnbaum RS, Plymate SR. Insulinlike growth factor-binding protein-2 and -3 expression in benign human prostate epithelium, prostate intraepithelial neoplasia, and adenocarcinoma of the prostate. J Clin Endocrinol Metab (1996) 81(1):411-20. doi:10.1210/jcem. 81.1.8550786

21. Thrasher JB, Tennant MK, Twomey PA, Hansberry KL, Wettlaufer JN, Plymate SR. Immunohistochemical localization of insulin-like growth factor binding proteins 2 and 3 in prostate tissue: clinical correlations. J Urol (1996) 155(3):999-1003. doi:10.1016/\$0022-5347(01)66367-5

22. Ho PJ, Baxter RC. Insulin-like growth factor-binding protein-2 in patients with prostate carcinoma and benign prostatic hyperplasia. Clin Endocrinol (Oxf) (1997) 46(3):333-42. doi:10.1046/j.1365-2265.1997.1100922.x 
23. Yu H, Nicar MR, Shi R, Berkel HJ, Nam R, Trachtenberg J, et al. Levels of insulin-like growth factor I (IGF-I) and IGF binding proteins 2 and 3 in serial postoperative serum samples and risk of prostate cancer recurrence. Urology (2001) 57(3):471-5. doi:10.1016/S0090-4295(00)01003-7

24. Shariat SF, Lamb DJ, Kattan MW, Nguyen C, Kim J, Beck J, et al. Association of preoperative plasma levels of insulin-like growth factor I and insulin-like growth factor binding proteins-2 and -3 with prostate cancer invasion, progression, and metastasis. J Clin Oncol (2002) 20(3):833-41. doi:10.1200/JCO.20.3.833

25. Richardsen E, Ukkonen T, Bjørnsen T, Mortensen E, Egevad L, Busch C. Overexpression of IGBFB2 is a marker for malignant transformation in prostate epithelium. Virchows Arch (2003) 442(4):329-35. doi:10.1007/s00428-0030786-2

26. Inman BA, Harel F, Audet JF, Meyer F, Douville P, Fradet Y, et al. Insulinlike growth factor binding protein 2: an androgen-dependent predictor of prostate cancer survival. Eur Urol (2005) 47(5):695-702. doi:10.1016/j.eururo. 2004.12.015

27. Ambrosini-Spaltro A, Farnedi A, Montironi R, Foschini MP. IGFBP2 as an immunohistochemical marker for prostatic adenocarcinoma. Appl Immunohistochem Mol Morphol (2011) 19(4):318-28. doi:10.1097/PAI. 0b013e3128052936

28. Flyvbjerg A, Mogensen O, Mogensen B, Nielsen OS. Elevated serum insulinlike growth factor-binding protein 2 (IGFBP-2) and decreased IGFBP-3 in epithelial ovarian cancer: correlation with cancer antigen 125 and tumorassociated trypsin inhibitor. J Clin Endocrinol Metab (1997) 82(7):2308-13. doi:10.1210/jc.82.7.2308

29. Hough CD, Cho KR, Zonderman AB, Schwartz DR, Morin PJ. Coordinately up-regulated genes in ovarian cancer. Cancer Res (2001) 61(10):3869-76.

30. Baron-Hay S, Boyle F, Ferrier A, Scott C. Elevated serum insulin-like growth factor binding protein-2 as a prognostic marker in patients with ovarian cancer. Clin Cancer Res (2004) 10(5):1796-806. doi:10.1158/1078-0432.CCR-0672-2

31. Lancaster JM, Sayer RA, Blanchette C, Calingaert B, Konidari I, Gray J, et al. High expression of insulin-like growth factor binding protein-2 messenger RNA in epithelial ovarian cancers produces elevated preoperative serum levels. Int J Gynecol Cancer (2006) 16(4):1529-35. doi:10.1111/j.1525-1438.2006. 00623.x

32. Yan XJ, Tian Y, Wang C, Wang XL, Di JM, Cheng JX. [The expressions and clinical significance of IGFBP-2, -3 in both serum and tumor tissues in patients with epithelial ovarian cancer]. Sichuan Da Xue Xue Bao Yi Xue Ban (2009) 40(4):639-43.

33. Urban N, Thorpe JD, Bergan LA, Forrest RM, Kampani AV, Scholler N, et al. Potential role of HE4 in multimodal screening for epithelial ovarian cancer. J Natl Cancer Inst (2011) 103(21):1630-4. doi:10.1093/jnci/djr359

34. Ollberding NJ, Cheng I, Wilkens LR, Henderson BE, Pollak MN, Kolonel LN, et al. Genetic variants, prediagnostic circulating levels of insulin-like growth factors, insulin, and glucose and the risk of colorectal cancer: the multiethnic cohort study. Cancer Epidemiol Biomarkers Prev (2012) 21(5):810-20. doi:10.1158/1055-9965.EPI-11-1105

35. Ladd JJ, Busald T, Johnson MM, Zhang Q, Pitteri SJ, Wang H, et al. Increased plasma levels of the APC-interacting protein MAPRE1, LRG1, and IGFBP2 preceding a diagnosis of colorectal cancer in women. Cancer Prev Res (Phila) (2012) 5(4):655-64. doi:10.1158/1940-6207.CAPR-11-0412

36. Liou JM, Shun CT, Liang JT, Chiu HM, Chen MJ, Chen CC, et al. Plasma insulin-like growth factor-binding protein-2 levels as diagnostic and prognostic biomarker of colorectal cancer. J Clin Endocrinol Metab (2010) 95(4):1717-25. doi:10.1210/jc.2009-2668

37. Lancashire LJ, Roberts DL, Dive C, Renehan AG. The development of composite circulating biomarker models for use in anticancer drug clinical development. Int J Cancer (2011) 128(8):1843-51. doi:10.1002/ijc.25513

38. Renehan AG, Painter JE, O'Halloran D, Atkin WS, Potten CS, O’Dwyer ST, et al. Circulating insulin-like growth factor II and colorectal adenomas. J Clin Endocrinol Metab (2000) 85(9):3402-8. doi:10.1210/jcem.85.9.6770

39. Renehan AG, Jones J, Potten CS, Shalet SM, O’Dwyer ST. Elevated serum insulin-like growth factor (IGF)-II and IGF binding protein-2 in patients with colorectal cancer. Br J Cancer (2000) 83(10):1344-50. doi:10.1054/bjoc. 2000.1462

40. el Atiq F, Garrouste F, Remacle-Bonnet M, Sastre B, Pommier G. Alterations in serum levels of insulin-like growth factors and insulin-like growthfactor-binding proteins in patients with colorectal cancer. Int J Cancer (1994) 57(4):491-7. doi:10.1002/ijc.2910570409
41. Dawczynski K, Steinbach D, Wittig S, Pfaffendorf N, Kauf E, Zintl F. Expression of components of the IGF axis in childhood acute myelogenous leukemia. Pediatr Blood Cancer (2008) 50(1):24-8. doi:10.1002/pbc.21294

42. Dawczynski K, Kauf E, Schlenvoigt D, Gruhn B, Fuchs D, Zintl F. Elevated serum insulin-like growth factor binding protein-2 is associated with a high relapse risk after hematopoietic stem cell transplantation in childhood AML. Bone Marrow Transplant (2006) 37(6):589-94. doi:10.1038/sj.bmt. 1705281

43. Zakhary NI, Boshra SA, El-Sawalhi MM, Fahim AT, Ebeid EN. Insulin-like growth factor system in Egyptian children with acute lymphoblastic leukemia. Genet Test Mol Biomarkers (2012) 16(9):1067-72. doi:10.1089/gtmb.2012.0039

44. Crofton PM, Ahmed SF, Wade JC, Elmlinger MW, Ranke MB, Kelnar CJ, et al. Bone turnover and growth during and after continuing chemotherapy in children with acute lymphoblastic leukemia. Pediatr Res (2000) 48(4):490-6. doi:10.1203/00006450-200010000-00012

45. Ansari D, Aronsson L, Sasor A, Welinder C, Rezeli M, Marko-Varga G, et al. The role of quantitative mass spectrometry in the discovery of pancreatic cancer biomarkers for translational science. J Transl Med (2014) 12:87. doi:10.1186/1479-5876-12-87

46. Kendrick ZW, Firpo MA, Repko RC, Scaife CL, Adler DG, Boucher KM, et al. Serum IGFBP2 and MSLN as diagnostic and prognostic biomarkers for pancreatic cancer. HPB (Oxford) (2014) 16(7):670-6. doi:10.1111/hpb.12199

47. McCaffery I, Tudor Y, Deng H, Tang R, Suzuki S, Badola S, et al. Putative predictive biomarkers of survival in patients with metastatic pancreatic adenocarcinoma treated with gemcitabine and ganitumab, an IGF1R inhibitor. Clin Cancer Res (2013) 19(15):4282-9. doi:10.1158/1078-0432.CCR-12-1840

48. Chen R, Brentnall TA, Pan S, Cooke K, Moyes KW, Lane Z, et al. Quantitative proteomics analysis reveals that proteins differentially expressed in chronic pancreatitis are also frequently involved in pancreatic cancer. Mol Cell Proteomics (2007) 6(8):1331-42. doi:10.1074/mcp.M700072-MCP200

49. Lee DY, Kim SJ, Lee YC. Serum insulin-like growth factor (IGF)-I and IGFbinding proteins in lung cancer patients. J Korean Med Sci (1999) 14(4):401-4 doi:10.3346/jkms.1999.14.4.401

50. Migita T, Narita T, Asaka R, Miyagi E, Nagano H, Nomura K, et al. Role of insulin-like growth factor binding protein 2 in lung adenocarcinoma: IGF-independent antiapoptotic effect via caspase-3. Am J Pathol (2010) 176(4):1756-66. doi:10.2353/ajpath.2010.090500

51. Yu CJ, Wang CL, Wang CI, Chen CD, Dan YM, Wu CC, et al. Comprehensive proteome analysis of malignant pleural effusion for lung cancer biomarker discovery by using multidimensional protein identification technology. J Proteome Res (2011) 10(10):4671-82. doi:10.1021/pr2004743

52. Guo C, Lu H, Gao W, Wang L, Lu K, Wu S, et al. Insulin-like growth factor binding protein-2 level is increased in blood of lung cancer patients and associated with poor survival. PLoS One (2013) 8(9):e74973. doi:10.1371/journal. pone. 0074973

53. Kim YW, Bae SM, Park DC, Lee KH, Liu HB, Kim IW, et al. Target-based molecular signature characteristics of cervical adenocarcinoma and squamous cell carcinoma. Int J Oncol (2013) 43(2):539-47. doi:10.3892/ijo.2013.1961

54. Eiseman JL, Guo J, Ramanathan RK, Belani CP, Solit DB, Scher HI, et al. Evaluation of plasma insulin-like growth factor binding protein 2 and Her-2 extracellular domain as biomarkers for 17-allylamino-17-demethoxygeldanamycin treatment of adult patients with advanced solid tumors. Clin Cancer Res (2007) 13(7):2121-7. doi:10.1158/1078-0432.CCR-06-2286

55. Wang H, Arun BK, Fuller GN, Zhang W, Middleton LP, Sahin AA. IGFBP2 and IGFBP5 overexpression correlates with the lymph node metastasis in T1 breast carcinomas. Breast J (2008) 14(3):261-7. doi:10.1111/j.1524-4741.2008. 00572.x

56. Sohn J, Do KA, Liu S, Chen H, Mills GB, Hortobagyi GN, et al. Functional proteomics characterization of residual triple-negative breast cancer after standard neoadjuvant chemotherapy. Ann Oncol (2013) 24(10):2522-6. doi:10.1093/annonc/mdt248

57. Ranke MB, Maier KP, Schweizer R, Stadler B, Schleicher S, Elmlinger MW, et al. Pilot study of elevated levels of insulin-like growth factor-binding protein2 as indicators of hepatocellular carcinoma. Horm Res (2003) 60(4):174-80. doi:10.1159/000073229

58. Lee CF, Ling ZQ, Zhao T, Lee KR. Distinct expression patterns in hepatitis B virus- and hepatitis $\mathrm{C}$ virus-infected hepatocellular carcinoma. World J Gastroenterol (2008) 14(39):6072-7. doi:10.3748/wjg.14.6072

59. Li N, Long Y, Fan X, Liu H, Li C, Chen L, et al. Proteomic analysis of differentially expressed proteins in hepatitis B virus-related hepatocellular 
carcinoma tissues. J Exp Clin Cancer Res (2009) 28:122. doi:10.1186/17569966-28-122

60. Zhou Q, Mao YQ, Jiang WD, Chen YR, Huang RY, Zhou XB, et al. Development of IGF signaling antibody arrays for the identification of hepatocellular carcinoma biomarkers. PLoS One (2012) 7(10):e46851. doi:10.1371/journal. pone.0046851

61. Matuschek C, Rudoy M, Peiper M, Gerber PA, Hoff NP, Buhren BA, et al. Do insulin-like growth factor associated proteins qualify as a tumor marker? Results of a prospective study in 163 cancer patients. Eur J Med Res (2011) 16(10):451-6. doi:10.1186/2047-783X-16-10-451

62. Tombolan L, Orso F, Guzzardo V, Casara S, Zin A, Bonora M, et al. High IGFBP2 expression correlates with tumor severity in pediatric rhabdomyosarcoma. Am J Pathol (2011) 179(5):2611-24. doi:10.1016/j.ajpath.2011.07.018

63. Fottner C, Sattarova S, Hoffmann K, Spöttl G, Weber MM. Elevated serum levels of IGF-binding protein 2 in patients with non-seminomatous germ cell cancer: correlation with tumor markers alpha-fetoprotein and human chorionic gonadotropin. Eur J Endocrinol (2008) 159(3):317-27. doi:10.1530/EJE08-0033

64. Zhang L, Huang W, Chen J, Zhou X, Lu Z, Zhou H. Expression of IGFBP2 in gastric carcinoma and relationship with clinicopathologic parameters and cell proliferation. Dig Dis Sci (2007) 52(1):248-53. doi:10.1007/s10620-0069358-z

65. Allander SV, Illei PB, Chen Y, Antonescu CR, Bittner M, Ladanyi M, et al. Expression profiling of synovial sarcoma by cDNA microarrays: association of ERBB2, IGFBP2, and ELF3 with epithelial differentiation. Am J Pathol (2002) 161(5):1587-95. doi:10.1016/S0002-9440(10)64437-9

66. Boulle N, Baudin E, Gicquel C, Logié A, Bertherat J, Penfornis A, et al. Evaluation of plasma insulin-like growth factor binding protein-2 as a marker for adrenocortical tumors. Eur J Endocrinol (2001) 144(1):29-36. doi:10.1530/eje. 0.1440029

67. Zumkeller W, Schwander J, Mitchell CD, Morrell DJ, Schofield PN, Preece MA. Insulin-like growth factor (IGF)-I, -II and IGF binding protein-2 (IGFBP2) in the plasma of children with Wilms' tumour. Eur J Cancer (1993) 29A(14):1973-7. doi:10.1016/0959-8049(93)90455-O

68. Baxter RC. IGF binding proteins in cancer: mechanistic and clinical insights. Nat Rev Cancer (2014) 14(5):329-41. doi:10.1038/nrc3720

69. Wheatcroft SB, Kearney MT. IGF-dependent and IGF-independent actions of IGF-binding protein-1 and -2: implications for metabolic homeostasis. Trends Endocrinol Metab (2009) 20(4):153-62. doi:10.1016/j.tem.2009.01.002

70. Ahmed RL, Thomas W, Schmitz KH. Interactions between insulin, body fat, and insulin-like growth factor axis proteins. Cancer Epidemiol Biomarkers Prev (2007) 16(3):593-7. doi:10.1158/1055-9965.EPI-06-0775

71. Carmichael AR. Obesity and prognosis of breast cancer. Obes Rev (2006) 7(4):333-40. doi:10.1111/j.1467-789X.2006.00261.x

72. Mattsson A, Svensson D, Schuett B, Osterziel KJ, Ranke MB. Multidimensional reference regions for IGF-I, IGFBP-2 and IGFBP-3 concentrations in serum of healthy adults. Growth Horm IGF Res (2008) 18(6):506-16. doi:10.1016/j.ghir.2008.04.005

73. Gunnell D, Oliver SE, Donovan JL, Peters TJ, Gillatt D, Persad R, et al. Do height-related variations in insulin-like growth factors underlie the associations of stature with adult chronic disease? J Clin Endocrinol Metab (2004) 89(1):213-8. doi:10.1210/jc.2003-030507

74. Helle SI, Ekse D, Holly JM, Lønning PE. The IGF-system in healthy pre- and postmenopausal women: relations to demographic variables and sex-steroids. J Steroid Biochem Mol Biol (2002) 81(1):95-102. doi:10.1016/S0960-0760(02) 00052-3

75. Voskuil DW, Bueno de Mesquita HB, Kaaks R, van Noord PA, Rinaldi S, Riboli E, et al. Determinants of circulating insulin-like growth factor (IGF)-I and IGF binding proteins 1-3 in premenopausal women: physical activity and anthropometry (Netherlands). Cancer Causes Control (2001) 12(10):951-8. doi:10.1023/A:1013708627664

76. Keinan-Boker L, Bueno De Mesquita HB, Kaaks R, Van Gils CH, Van Noord PA, Rinaldi S, et al. Circulating levels of insulin-like growth factor I, its binding proteins -1,-2, -3, C-peptide and risk of postmenopausal breast cancer. Int J Cancer (2003) 106(1):90-5. doi:10.1002/ijc.11193

77. Ngo TH, Barnard RJ, Cohen P, Freedland S, Tran C, deGregorio F, et al. Effect of isocaloric low-fat diet on human LAPC-4 prostate cancer xenografts in severe combined immunodeficient mice and the insulin-like growth factor axis. Clin Cancer Res (2003) 9(7):2734-43.
78. Clemmons DR, Snyder DK, Busby WH. Variables controlling the secretion of insulin-like growth factor binding protein-2 in normal human subjects. J Clin Endocrinol Metab (1991) 73(4):727-33. doi:10.1210/jcem-73-4-727

79. van den Beld AW, Blum WF, Brugts MP, Janssen JA, Grobbee DE, Lamberts SW. High IGFBP2 levels are not only associated with a better metabolic risk profile but also with increased mortality in elderly men. Eur J Endocrinol (2012) 167(1):111-7. doi:10.1530/EJE-12-0160

80. Probst-Hensch NM, Steiner JH, Schraml P, Varga Z, Zürrer-Härdi U, Storz M, et al. IGFBP2 and IGFBP3 protein expressions in human breast cancer: association with hormonal factors and obesity. Clin Cancer Res (2010) 16(3):1025-32. doi:10.1158/1078-0432.CCR-09-0957

81. So AI, Levitt RJ, Eigl B, Fazli L, Muramaki M, Leung S, et al. Insulin-like growth factor binding protein-2 is a novel therapeutic target associated with breast cancer. Clin Cancer Res (2008) 14(21):6944-54. doi:10.1158/1078-0432.CCR08-0408

82. Renehan AG, Frystyk J, Flyvbjerg A. Obesity and cancer risk: the role of the insulin-IGF axis. Trends Endocrinol Metab (2006) 17(8):328-36. doi:10.1016/j. tem.2006.08.006

83. Hoeflich A, Wu M, Mohan S, Föll J, Wanke R, Froehlich T, et al. Overexpression of insulin-like growth factor-binding protein-2 in transgenic mice reduces postnatal body weight gain. Endocrinology (1999) 140(12):5488-96. doi:10.1210/endo.140.12.7169

84. Diehl D, Hessel E, Oesterle D, Renner-Müller I, Elmlinger M, Langhammer M, et al. IGFBP-2 overexpression reduces the appearance of dysplastic aberrant crypt foci and inhibits growth of adenomas in chemically induced colorectal carcinogenesis. Int J Cancer (2009) 124(9):2220-5. doi:10.1002/ijc.24193

85. Miraki-Moud F, Jenkins PJ, Fairclough PD, Jordan S, Bustin SA, Jones AM, et al. Increased levels of insulin-like growth factor binding protein-2 in sera and tumours from patients with colonic neoplasia with and without acromegaly. Clin Endocrinol (Oxf) (2001) 54(4):499-508. doi:10.1046/j.1365-2265.2001. 01221.x

86. Yazawa T, Sato H, Shimoyamada H, Okudela K, Woo T, Tajiri M, et al. Neuroendocrine cancer-specific up-regulating mechanism of insulin-like growth factor binding protein-2 in small cell lung cancer. Am J Pathol (2009) 175(3):976-87. doi:10.2353/ajpath.2009.081004

87. He Y, Zhou Z, Hofstetter WL, Zhou Y, Hu W, Guo C, et al. Aberrant expression of proteins involved in signal transduction and DNA repair pathways in lung cancer and their association with clinical parameters. PLoS One (2012) 7(2):e31087. doi:10.1371/journal.pone.0031087

88. Hoeflich A, Wirthgen E, David R, Classen CF, Spitschak M, Brenmoehl J. Control of IGFBP-2 expression by steroids and peptide hormones in vertebrates. Front Endocrinol (Lausanne) (2014) 5:43. doi:10.3389/fendo.2014.00043

89. Uhlen M, Oksvold P, Fagerberg L, Lundberg E, Jonasson K, Forsberg M, et al. Towards a knowledge-based human protein atlas. Nat Biotechnol (2010) 28(12):1248-50. doi:10.1038/nbt1210-1248

90. Consortium EP. An integrated encyclopedia of DNA elements in the human genome. Nature (2012) 489(7414):57-74. doi:10.1038/nature11247

91. McRonald FE, Morris MR, Gentle D, Winchester L, Baban D, Ragoussis J, et al. CpG methylation profiling in VHL related and VHL unrelated renal cell carcinoma. Mol Cancer (2009) 8:31. doi:10.1186/1476-4598-8-31

92. Simons CC, van den Brandt PA, Stehouwer CD, van Engeland M, Weijenberg MP. Body size, physical activity, early-life energy restriction, and associations with methylated insulin-like growth factor-binding protein genes in colorectal cancer. Cancer Epidemiol Biomarkers Prev (2014) 23(9):1852-62. doi:10.1158/1055-9965.EPI-13-1285

93. Chiba T, Yokosuka O, Fukai K, Hirasawa Y, Tada M, Mikata R, et al. Identification and investigation of methylated genes in hepatoma. Eur J Cancer (2005) 41(8):1185-94. doi:10.1016/j.ejca.2005.02.014

94. Fukushima T, Tezuka T, Shimomura T, Nakano S, Kataoka H. Silencing of insulin-like growth factor-binding protein-2 in human glioblastoma cells reduces both invasiveness and expression of progression-associated gene CD24. J Biol Chem (2007) 282(25):18634-44. doi:10.1074/jbc.M609567200

95. Neri F, Krepelova A, Incarnato D, Maldotti M, Parlato C, Galvagni F, et al. Dnmt3L antagonizes DNA methylation at bivalent promoters and favors DNA methylation at gene bodies in ESCs. Cell (2013) 155(1):121-34. doi:10.1016/j. cell.2013.08.056

96. Takeo C, Ikeda K, Horie-Inoue K, Inoue S. Identification of Igf2, Igfbp2 and Enpp2 as estrogen-responsive genes in rat hippocampus. Endocr J (2009) 56(1):113-20. doi:10.1507/endocrj.K08E-220 
97. Sárvári M, Kalló I, Hrabovszky E, Solymosi N, Tóth K, Likó I, et al. Estradiol replacement alters expression of genes related to neurotransmission and immune surveillance in the frontal cortex of middle-aged, ovariectomized rats. Endocrinology (2010) 151(8):3847-62. doi:10.1210/en.2010-0375

98. Suzuki A, Urushitani H, Watanabe H, Sato T, Iguchi T, Kobayashi T, et al. Comparison of estrogen responsive genes in the mouse uterus, vagina and mammary gland. J Vet Med Sci (2007) 69(7):725-31. doi:10.1292/jvms.69.725

99. Korc-Grodzicki B, Ren N, Hilf R. Effects of estradiol on the expression and production of IGFBP-2 by R3230AC mammary tumor cells. Oncol Res (1996) 8(12):473-83.

100. Martin JL, Baxter RC. Expression of insulin-like growth factor binding protein2 by MCF-7 breast cancer cells is regulated through the phosphatidylinositol 3-kinase/AKT/mammalian target of rapamycin pathway. Endocrinology (2007) 148(5):2532-41. doi:10.1210/en.2006-1335

101. Akkiprik M, Nicorici D, Cogdell D, Jia YJ, Hategan A, Tabus I, et al. Dissection of signaling pathways in fourteen breast cancer cell lines using reversephase protein lysate microarray. Technol Cancer Res Treat (2006) 5(6):543-51. doi:10.1177/153303460600500601

102. Maxwell P, van den Berg HW. Changes in the secretion of insulin-like growth factor binding proteins -2 and -4 associated with the development of tamoxifen resistance and estrogen independence in human breast cancer cell lines. Cancer Lett (1999) 139(2):121-7. doi:10.1016/S0304-3835(99)00009-9

103. de Bont JM, van Doorn J, Reddingius RE, Graat GH, Passier MM, den Boer $\mathrm{ML}$, et al. Various components of the insulin-like growth factor system in tumor tissue, cerebrospinal fluid and peripheral blood of pediatric medulloblastoma and ependymoma patients. Int J Cancer (2008) 123(3):594-600. doi:10.1002/ijc.23558

104. Berg U, Bang P, Carlsson-Skwirut C. Calpain proteolysis of insulin-like growth factor binding protein (IGFBP) -2 and -3 , but not of IGFBP-1. Biol Chem (2007) 388(8):859-63. doi:10.1515/BC.2007.098

105. Monget P, Mazerbourg S, Delpuech T, Maurel MC, Manière S, Zapf J, et al. Pregnancy-associated plasma protein-A is involved in insulin-like growth factor binding protein-2 (IGFBP-2) proteolytic degradation in bovine and porcine preovulatory follicles: identification of cleavage site and characterization of IGFBP-2 degradation. Biol Reprod (2003) 68(1):77-86. doi:10.1095/ biolreprod.102.007609

106. Réhault S, Monget P, Mazerbourg S, Tremblay R, Gutman N, Gauthier F, et al. Insulin-like growth factor binding proteins (IGFBPs) as potential physiological substrates for human kallikreins hK2 and hK3. Eur J Biochem (2001) 268(10):2960-8. doi:10.1046/j.1432-1327.2001.02185.x

107. Miyamoto S, Nakamura M, Yano K, Ishii G, Hasebe T, Endoh Y, et al. Matrix metalloproteinase-7 triggers the matricrine action of insulin-like growth factor-II via proteinase activity on insulin-like growth factor binding protein 2 in the extracellular matrix. Cancer Sci (2007) 98(5):685-91. doi:10.1111/j.1349-7006.2007.00448.x

108. Soh CL, McNeil K, Owczarek CM, Hardy MP, Fabri LJ, Pearse M, et al. Exogenous administration of protease-resistant, non-matrix-binding IGFBP-2 inhibits tumour growth in a murine model of breast cancer. Br J Cancer (2014) 110(12):2855-64. doi:10.1038/bjc.2014.232

109. Forbes BE, McCarthy P, Norton RS. Insulin-like growth factor binding proteins: a structural perspective. Front Endocrinol (Lausanne) (2012) 3:38. doi:10.3389/fendo.2012.00038

110. Mark S, Kübler B, Höning S, Oesterreicher S, John H, Braulke T, et al. Diversity of human insulin-like growth factor (IGF) binding protein-2 fragments in plasma: primary structure, IGF-binding properties, and disulfide bonding pattern. Biochemistry (2005) 44(9):3644-52. doi:10.1021/bi0478401

111. Kuang Z, Yao S, McNeil KA, Thompson JA, Bach LA, Forbes BE, et al. Cooperativity of the $\mathrm{N}$ - and $\mathrm{C}$-terminal domains of insulin-like growth factor (IGF) binding protein 2 in IGF binding. Biochemistry (2007) 46(48):13720-32. doi:10.1021/bi701251d

112. Kibbey MM, Jameson MJ, Eaton EM, Rosenzweig SA. Insulin-like growth factor binding protein-2: contributions of the C-terminal domain to insulin-like growth factor-1 binding. Mol Pharmacol (2006) 69(3):833-45. doi:10.1124/ mol.105.016998

113. Storr SJ, Carragher NO, Frame MC, Parr T, Martin SG. The calpain system and cancer. Nat Rev Cancer (2011) 11(5):364-74. doi:10.1038/nrc3050

114. Hadler-Olsen E, Winberg JO, Uhlin-Hansen L. Matrix metalloproteinases in cancer: their value as diagnostic and prognostic markers and therapeutic targets. Tumour Biol (2013) 34(4):2041-51. doi:10.1007/s13277013-0842-8

115. Oikonomopoulou K, Diamandis EP, Hollenberg MD. Kallikrein-related peptidases: proteolysis and signaling in cancer, the new frontier. Biol Chem (2010) 391(4):299-310. doi:10.1515/BC.2010.038

116. Martino-Echarri E, Fernández-Rodríguez R, Bech-Serra JJ, Plaza-Calonge Mdel C, Vidal N, Casal C, et al. Relevance of IGFBP2 proteolysis in glioma and contribution of the extracellular protease ADAMTS1. Oncotarget (2014) 5(12):4295-304.

117. Kiepe D, Van Der Pas A, Ciarmatori S, Ständker L, Schütt B, Hoeflich A, et al. Defined carboxy-terminal fragments of insulin-like growth factor (IGF) binding protein-2 exert similar mitogenic activity on cultured rat growth plate chondrocytes as IGF-I. Endocrinology (2008) 149(10):4901-11. doi:10.1210/en.2007-1395

118. Azar WJ, Zivkovic S, Werther GA, Russo VC. IGFBP-2 nuclear translocation is mediated by a functional NLS sequence and is essential for its protumorigenic actions in cancer cells. Oncogene (2014) 33(5):578-88. doi:10. 1038/onc. 2012.630

119. Juncker-Jensen A, Lykkesfeldt AE, Worm J, Ralfkiaer U, Espelund U, Jepsen JS. Insulin-like growth factor binding protein 2 is a marker for antiestrogen resistant human breast cancer cell lines but is not a major growth regulator. Growth Horm IGF Res (2006) 16(4):224-39. doi:10.1016/j.ghir.2006.06.005

120. Chesik D, Kühl NM, Wilczak N, De Keyser J. Enhanced production and proteolytic degradation of insulin-like growth factor binding protein-2 in proliferating rat astrocytes. J Neurosci Res (2004) 77(3):354-62. doi:10.1002/jnr.20172

121. Hoelzinger DB, Mariani L, Weis J, Woyke T, Berens TJ, McDonough WS, et al. Gene expression profile of glioblastoma multiforme invasive phenotype points to new therapeutic targets. Neoplasia (2005) 7(1):7-16. doi:10.1593/neo.04535

122. Shelton LM, Mukherjee P, Huysentruyt LC, Urits I, Rosenberg JA, Seyfried TN. A novel pre-clinical in vivo mouse model for malignant brain tumor growth and invasion. J Neurooncol (2010) 99(2):165-76. doi:10.1007/s11060010-0115-y

123. Cazals V, Mouhieddine B, Maitre B, Le Bouc Y, Chadelat K, Brody JS, et al. Insulin-like growth factors, their binding proteins, and transforming growth factor-beta 1 in oxidant-arrested lung alveolar epithelial cells. J Biol Chem (1994) 269(19):14111-7.

124. Chetty A, Manzo N, Waxman AB, Nielsen HC. Modulation of IGF-binding protein-2 and -3 in hyperoxic injury in developing rat lung. Pediatr Res (2005) 58(2):222-8. doi:10.1203/01.PDR.0000169973.42653.68

125. Liu HC, Chang LW, Rong ZH, Zhu HP, Zhang QS, Chen HB, et al. [Relation of insulin-like growth factor binding protein-2 with hyperoxia-induced lung injury in term and premature neonatal rats]. Zhongguo Wei Zhong Bing Ji Jiu Yi Xue (2008) 20(6):331-4. doi:10.3736/jcim20080401

126. Averbukh E, Weiss O, Halpert M, Yanko R, Moshe R, Nephesh I, et al. Gene expression of insulin-like growth factor-I, its receptor and binding proteins in retina under hypoxic conditions. Metabolism (1998) 47(11):1331-6. doi:10.1016/S0026-0495(98)90300-6

127. Dean SJ, Perks CM, Holly JM, Bhoo-Pathy N, Looi LM, Mohammed NA, et al. Loss of PTEN expression is associated with IGFBP2 expression, younger age, and late stage in triple-negative breast cancer. Am J Clin Pathol (2014) 141(3):323-33. doi:10.1309/AJCPR11DEAYPTUSL

128. Perks CM, Vernon EG, Rosendahl AH, Tonge D, Holly JM. IGF-II and IGFBP-2 differentially regulate PTEN in human breast cancer cells. Oncogene (2007) 26(40):5966-72. doi:10.1038/si.onc.1210397

129. Mehrian-Shai R, Chen CD, Shi T, Horvath S, Nelson SF, Reichardt JK, et al. Insulin growth factor-binding protein 2 is a candidate biomarker for PTEN status and PI3K/Akt pathway activation in glioblastoma and prostate cancer. Proc Natl Acad Sci U S A (2007) 104(13):5563-8. doi:10.1073/pnas.0609139104

130. Levitt RJ, Georgescu MM, Pollak M. PTEN-induction in U251 glioma cells decreases the expression of insulin-like growth factor binding protein-2. Biochem Biophys Res Commun (2005) 336(4):1056-61. doi:10.1016/j.bbrc. 2005.08.229

131. Sato H, Yazawa T, Suzuki T, Shimoyamada H, Okudela K, Ikeda M, et al. Growth regulation via insulin-like growth factor binding protein-4 and -2 in association with mutant K-ras in lung epithelia. Am J Pathol (2006) 169(5):1550-66. doi:10.2353/ajpath.2006.051068

132. Grimberg A, Coleman CM, Shi Z, Burns TF, MacLachlan TK, Wang W, et al. Insulin-like growth factor binding protein-2 is a novel mediator of p53 
inhibition of insulin-like growth factor signaling. Cancer Biol Ther (2006) 5(10):1408-14. doi:10.4161/cbt.5.10.3455

133. Milewicz T, Rys J, Wójtowicz A, Stochmal E, Jach R, Krzysiek J, et al. Overexpression of P53 protein and local hGH, IGF-I, IGFBP-3, IGFBP-2 and PRL secretion by human breast cancer explants. Neuro Endocrinol Lett (2011) 32(3):328-33.

134. Coppé JP, Patil CK, Rodier F, Sun Y, Muñoz DP, Goldstein J, et al. Senescenceassociated secretory phenotypes reveal cell-nonautonomous functions of oncogenic RAS and the p53 tumor suppressor. PLoS Biol (2008) 6(12):2853-68. doi:10.1371/journal.pbio.0060301

135. Hjelmeland LM, Cristofolo VJ, Funk W, Rakoczy E, Katz ML. Senescence of the retinal pigment epithelium. Mol Vis (1999) 5:33.

136. Matsunaga H, Handa JT, Gelfman CM, Hjelmeland LM. The mRNA phenotype of a human RPE cell line at replicative senescence. Mol Vis (1999) 5:39.

137. Shelton DN, Chang E, Whittier PS, Choi D, Funk WD. Microarray analysis of replicative senescence. Curr Biol (1999) 9(17):939-45. doi:10.1016/S09609822(99)80420-5

138. Busund LT, Richardsen E, Busund R, Ukkonen T, Bjørnsen T, Busch C, et al. Significant expression of IGFBP2 in breast cancer compared with benign lesions. J Clin Pathol (2005) 58(4):361-6. doi:10.1136/jcp.2004.020834

139. Wang H, Rosen DG, Fuller GN, Zhang W, Liu J. Insulin-like growth factorbinding protein 2 and 5 are differentially regulated in ovarian cancer of different histologic types. Mod Pathol (2006) 19(9):1149-56. doi:10.1038/modpathol. 3800637

140. Villani RM, Adolphe C, Palmer J, Waters MJ, Wainwright BJ. Patched 1 inhibits epidermal progenitor cell expansion and basal cell carcinoma formation by limiting Igfbp2 activity. Cancer Prev Res (Phila) (2010) 3(10):1222-34. doi:10.1158/1940-6207.CAPR-10-0082

141. Kang Z, Yu Y, Zhu YJ, Davis S, Walker R, Meltzer PS, et al. Downregulation of IGFBP2 is associated with resistance to IGF1R therapy in rhabdomyosarcoma. Oncogene (2014) 33(50):5697-705. doi:10.1038/onc.2013.509

142. Frommer KW, Reichenmiller K, Schutt BS, Hoeflich A, Ranke MB, Dodt G, et al. IGF-independent effects of IGFBP-2 on the human breast cancer cell line Hs578T. J Mol Endocrinol (2006) 37(1):13-23. doi:10.1677/jme.1.01955

143. Sakamoto M, Kondo A, Kawasaki K, Goto T, Sakamoto H, Miyake K, et al. Analysis of gene expression profiles associated with cisplatin resistance in human ovarian cancer cell lines and tissues using cDNA microarray. Hum Cell (2001) 14(4):305-15.

144. Lu H, Wang L, Gao W, Meng J, Dai B, Wu S, et al. IGFBP2/FAK pathway is causally associated with dasatinib resistance in non-small cell lung cancer cells. Mol Cancer Ther (2013) 12(12):2864-73. doi:10.1158/1535-7163.MCT13-0233
145. Biernacka KM, Uzoh CC, Zeng L, Persad RA, Bahl A, Gillatt D, et al. Hyperglycaemia-induced chemoresistance of prostate cancer cells due to IGFBP2. Endocr Relat Cancer (2013) 20(5):741-51. doi:10.1530/ERC13-0077

146. Kühnl A, Kaiser M, Neumann M, Fransecky L, Heesch S, Radmacher M, et al. High expression of IGFBP2 is associated with chemoresistance in adult acute myeloid leukemia. Leuk Res (2011) 35(12):1585-90. doi:10.1016/j.leukres. 2011.08.006

147. Han S, Meng L, Wang Y, Wu A. Plasma IGFBP-2 levels after postoperative combined radiotherapy and chemotherapy predict prognosis in elderly glioblastoma patients. PLoS One (2014) 9(4):e93791. doi:10.1371/journal. pone.0093791

148. Firth SM, Baxter RC. Cellular actions of the insulin-like growth factor binding proteins. Endocr Rev (2002) 23(6):824-54. doi:10.1210/er.2001-0033

149. Schütt BS, Langkamp M, Rauschnabel U, Ranke MB, Elmlinger MW. Integrinmediated action of insulin-like growth factor binding protein-2 in tumor cells. J Mol Endocrinol (2004) 32(3):859-68. doi:10.1677/jme.0.0320859

150. Mendes KN, Wang GK, Fuller GN, Zhang W. JNK mediates insulin-like growth factor binding protein $2 /$ integrin alpha5-dependent glioma cell migration. Int J Oncol (2010) 37(1):143-53. doi:10.3892/ijo_00000662

151. Han S, Li Z, Master LM, Master ZW, Wu A. Exogenous IGFBP-2 promotes proliferation, invasion, and chemoresistance to temozolomide in glioma cells via the integrin $\beta 1$-ERK pathway. Br J Cancer (2014) 111(7):1400-9. doi:10.1038/bjc.2014.435

Conflict of Interest Statement: The authors declare that the research was conducted in the absence of any commercial or financial relationships that could be construed as a potential conflict of interest.

Received: 15 January 2015; accepted: 13 February 2015; published online: 27 February 2015.

Citation: Pickard A and McCance DJ (2015) IGF-binding protein 2 - oncogene or tumor suppressor? Front. Endocrinol. 6:25. doi: 10.3389/fendo.2015.00025

This article was submitted to Cancer Endocrinology, a section of the journal Frontiers in Endocrinology.

Copyright (๑) 2015 Pickard and McCance. This is an open-access article distributed under the terms of the Creative Commons Attribution License (CC BY). The use, distribution or reproduction in other forums is permitted, provided the original author $(s)$ or licensor are credited and that the original publication in this journal is cited, in accordance with accepted academic practice. No use, distribution or reproduction is permitted which does not comply with these terms. 